San Antonio Review • San Antonio Review (Issue 2 | Winter 2019)

\title{
Over a Far City a Rainbow
}

\author{
Emma Lee
}

Published on: Apr 28, 2019

Updated on: Aug 30, 2020

License: Creative Commons Attribution 4.0 International License (CC-BY 4.0). 
A queen bee switched her daughter's diet to honey and pollen, withholding the royal jelly. She feared her hive had a second queen.

The queen's five eyes scoured her daughter's cell, kept it light so nothing was hidden. The larva was punished for any signs of independence.

An untended larvae will shrivel. Forced to become a worker, she gave the queen pre-digested news and praise but felt sick.

The queen buzzed rage at her daughter's failures, took credit for successes. The daughter owned nothing. She dieted in preparation to fly.

In a far city, the daughter found a room with a bed, a bookcase, a cupboard and desk. Band posters darkened the room's walls.

Record boxes and books overspilled the shelves. The daughter focused her listening to songs she could dream dance routines for.

A rainbow messaged: there are flowers here. In moonlight, the daughter grew and tested her wings. She didn't have to be the queen to live.

Emma Lee's most recent collection is Ghosts in the Desert (IDP, UK 2015). The Significance of a Dress is forthcoming from Arachne Press (UK). She co-edited Over Land, Over Sea (Five Leaves, UK, 2015) and reviews for The Blue Nib, High Window Journal, The Journal, London Grip and Sabotage Reviews. 